\title{
Environmental management of a scientific field camp in Maritime Antarctica: reconciling research impacts with conservation goals in remote ice-free areas
}

\author{
LUIS R. PERTIERRA ${ }^{1}$, KEVIN A. HUGHES ${ }^{2}$, JAVIER BENAYAS ${ }^{1}$, ANA JUSTEL ${ }^{3}$ and ANTONIO QUESADA ${ }^{4 *}$ \\ ${ }^{I}$ Departamento de Ecología, Universidad Autónoma de Madrid, 28049 Madrid, Spain \\ ${ }^{2}$ British Antarctic Survey, NERC, High Cross, Madingley Road, Cambridge CB3 OET, United Kingdom \\ ${ }^{3}$ Departamento de Matemáticas, Universidad Autónoma de Madrid, 28049 Madrid, Spain \\ ${ }^{4}$ Departamento de Biología, Universidad Autónoma de Madrid, 28049 Madrid, Spain \\ *corresponding author: antonio.quesada@uam.es
}

\begin{abstract}
Currently, a substantial proportion of Antarctic research is carried out through deployment of field camps, but little detailed information on the running of these facilities is often available. The remoteness of camps and the fragility of local Antarctic terrestrial ecosystems make the running of sustainable, low impact field science and logistics in ice-free areas a challenge for environmental managers. In this study we examined the environmental management at the Spanish camp within Antarctic Specially Protected Area (ASPA) No. 126 Byers Peninsula, Livingston Island, South Shetland Islands. Firstly, the input of materials and generation of pollution associated with the camp during a ten year period of operation was quantified. Examination of greenhouse gas emissions shows a mean of $14 \mathrm{tCO}_{2}$ equivalent per researcher associated with transportation of people to the site, plus $44 \mathrm{tCO}_{2}$ equivalent per researcher, associated with transportation of cargo to the field site. Secondly, the cumulative trampling footprint across Byers Peninsula and associated local impacts were recorded. Results showed the pattern of human movement within the ASPA and how activities concentrated around the field camp site. At the same time every effort was taken to ensure scientific outputs from research activities within the ASPA were maximized. Practical recommendations on operational logistics are discussed to minimize environmental impacts and optimize scientific benefits.
\end{abstract}

Received 22 February 2012, accepted 29 September 2012

Key words: carbon footprint, impact assessment, science, South Shetland Islands, terrestrial ecosystems

\section{Introduction}

Remote field camps are fundamental components of the terrestrial biological and geological research logistic programmes of many nations operating in Antarctica. Such field activities are bound by the legislation within the Protocol on Environmental Protection to the Antarctic Treaty which includes the mandatory assessment of environmental impacts associated with all activities within the Antarctic Treaty area. Remote field camps can be very different in nature, scale and spatial extent, but in each case the presence of researchers within field locations inevitably leads to some environmental impacts, which should be minimized to the maximum extent practicable. The Council of Managers of National Antarctic Programs (COMNAP) currently lists 81 research stations, 18 permanent or seasonal camps and two refuges within the Antarctic Treaty area (south of $60^{\circ} \mathrm{S}$ ) (COMNAP 2012). Using these data, field camps represented only $17 \%$ of all reported facilities, but the level of human activity within temporary camps has been severely under-reported. For example, there has been a Spanish summer field camp on Byers Peninsula since 2001, which has not been included in the COMNAP list, yet in that time it must have generated at least some impacts. How 'transitory' these impacts may have been needs to be assessed; for example, the human activities may have lead to the development of paths and/or the introduction of non-native macro- and micro-biota, which may have longer term consequences for the area (Convey 2008). The presence of temporary field camps established by two or more nations simultaneously at the same location may also have consequences for the environment and necessitate co-ordinated environmental management. For instance, a Chilean camp was simultaneously deployed during the 2010 season in Byers Peninsula beside the Spanish campsite, which led to additional environmental impacts in the local area (Fig. 1). Lack of information concerning the movement and activities of researchers from different nations may severely hamper the calculation of human footprint and cumulative impact of national operator activities within Antarctica. Some attempts have been made to establish the extent of human footprint over a wider spatial scale. Hughes et al. (2011) showed the location of UK field 


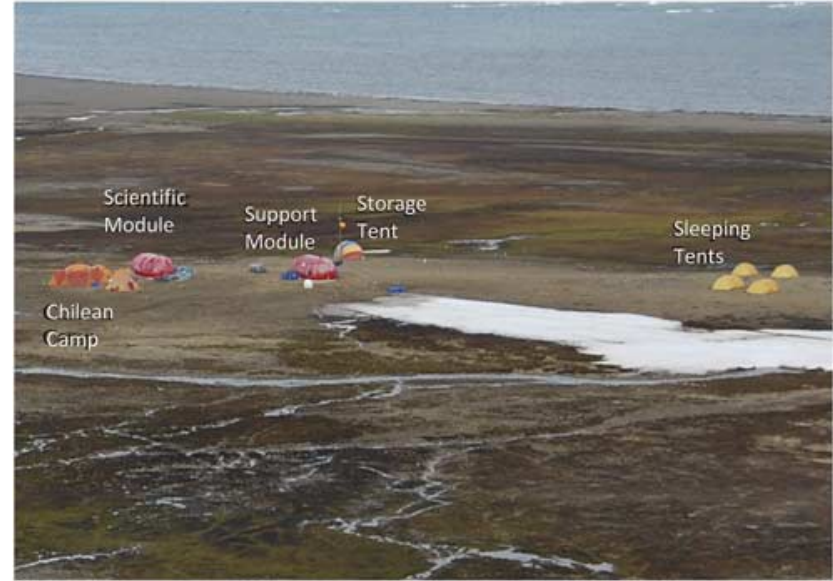

Fig. 1. View of the Spanish camp at South Beaches, Byers Peninsula. Picture taken on January 2010. Note that impacts associated with the Chilean camp are not included in this study.

sampling activities since the late 1940s and ice-free areas visited over much of the Antarctic Peninsula and beyond.

Levels of human occupation in field camps are generally much lower than on research stations. Typically, camps may contain from two to a dozen researchers compared with stations which can accommodate tens to several hundreds of personnel. However, field camps, although smaller and often more transient, may be considerably more numerous. Many stations act as staging posts to support field activities and temporary camps in remote locations. In many cases, the same biological and geological values that attract researchers and make necessary the temporary camps are also those values that are particularly vulnerable to human activity. Added to this, the remoteness of some field locations may generate logistical difficulties (Clarke et al. 2005) that make the maintenance of high environmental management standards problematic, e.g. ensuring waste is managed appropriately. Monitoring of long-term or cumulative impacts is rarely, if ever, routinely performed at field locations due to the transient nature of occupancy and the costs. Finally, re-use of camp facilities by subsequent expeditions may be irregular and closely linked with national funding of specific scientific topics for which the location is appropriate as a research site (whether this is geology, limnology, terrestrial biology, or more rarely a combination of scientific values).

In the case of field camps where the camp infrastructure is left in situ year-round the resulting impacts can be considered similar to bases although smaller in magnitude. Nevertheless, temporary camps still comprise most of the local impacts in remote areas. Described impacts in these areas include expansion of human footprint associated with land use and soil trampling (Campbell et al. 1998,
Ayres et al. 2008, Tejedo et al. 2009), unintentional nonnative species introduction (Frenot et al. 2005, Convey et al. 2006, Hughes \& Convey 2010), wastes (Connor 2008) and soil pollution (Evans et al. 2000, Snape et al. 2002). Inevitably, scientific research activity has an environmental cost including disturbance of neighbouring fauna (Pfeiffer 2005, De Villiers et al. 2006, De Villiers 2008), damage to vegetation (Gremmen et al. 2003, Pertierra et al. 2013) and direct interference with biotic and abiotic components of the local ecosystem associated with scientific sampling. A review of the scientific knowledge on impacts can be found in Olech (1996) and Tin et al. (2009).

In this paper we study the human impact associated with the activities of the Spanish camp (Fig. 1) which primarily accommodated Limnopolar expeditions (2001-10) in the surrounding area on Byers Peninsula. Limnopolar group research was focused primarily on limnological studies on Byers Peninsula and so the Spanish programme established a field camp in a small vegetation-free area at the South Beaches in 2001. Furthermore, this facility has also accommodated other groups with scientific interests on Byers Peninsula, and thus facilitated a wider range of investigations than included in this analysis. Under the auspices of the International Polar Year (IPY, 2007-09) 31 researchers from seven nations participated in the 2008-09 field campaign, hosted by the Spanish programme. The field camp used at this time was later declared the designated campsite in the revised management plan for ASPA No. 126 (ATCM 2011) and declared an 'International Field Camp'.

Byers Peninsula is an extensive ice-free area in the western part of Livingston Island (South Shetland Islands, $\left.62^{\circ} 34^{\prime} 35^{\prime \prime}-62^{\circ} 40^{\prime} 35^{\prime \prime} \mathrm{S}, 60^{\circ} 54^{\prime} 14^{\prime \prime}-61^{\circ} 13^{\prime} 07^{\prime \prime} \mathrm{W}\right)$. It contains numerous lakes, some of which formed comparatively recently, that have been the subject of extensive research by the Spanish Limnopolar research group since 2001. Byers Peninsula shows high biodiversity including breeding populations of elephant seals, gentoo penguin, giant petrels, skuas and other marine birds. Invertebrates include many species of collembola (springtails), acari (mites) and the dipterans Belgica antarctica Jacobs and Parochlus steinenii (Gerke). The vegetation is extremely diverse and abundant (Lindsay 1971), and includes Antarctica's only two native vascular plants (Deschampsia antarctica Desv. and Colobanthus quitensis (Kunth) Bartl.), around fifty moss species and over one hundred lichen species (ASPA No. 126 Management Plan, ATCM 2011). The peninsula also contains sites of geological interest and abandoned refuges and archaeological remains left by 19th century sealers (Smith \& Simpson 1987). In recognition of the uniqueness and importance of Byers Peninsula it was originally designated as a Specially Protected Area (SPA) in 1966, a Site of Special Scientific Interest (SSSI) in 1975 and finally an Antarctic Specially Protected Area (ASPA No. 126) in 1991, with the most recent version of the 
area's management plan agreed by the Antarctic Treaty Consultative Meeting (ATCM) in 2011. ASPA designation is the highest level of area protection within Antarctica and includes a management plan which must be consulted and adhered to by all those authorized by appropriate national authorities to enter the protected area.

The natural and scientific values of Byers Peninsula have been the subject of many studies in addition to those carried out by the Spanish camp and have resulted in the establishment of some other field camps located mainly at coastal locations. Over the last decades, research groups from several Antarctic Treaty Parties have established field camps in other areas of Byers Peninsula, including expeditions from the Argentina, Brazil, Chile, Spain, the United Kingdom and the United States. Although the camps were largely removed, it is still possible to identify the locations of some of these camps by the presence of litter/waste and disturbed ground. Away from the coast, scientists have left meteorological stations, sensors, plots, cairns and markers, some of which apparently are not maintained regularly and might, in effect, be abandoned. All expeditions that have been undertaken independently from the Spanish camp research in Byers Peninsula during the 2001-10 period have not been included in this assessment.

Field camps are important for Antarctic research, but little attempt has been made to monitor their impacts and often no record of their location is made available publically, making estimation of human footprint difficult. Intensity and spatial extent of local impacts are dictated by the number of visitors, how long they stay and where they go. These activities may accumulate over time to produce impacts that may be neither minor nor transitory, and may merit a higher level of environmental impact assessment such as an Initial Environmental Evaluation, as required in Annex I of the Environmental Protocol. Dedicated management measures are necessary to ensure the effective protection of the Antarctic environment. These include integral Environmental Impact Assessments (EIAs) with minimization, mitigation and monitoring of impacts (Bastmeijer \& Roura 2007, Tin et al. 2009). The example of the Spanish camp is presented to contribute to the evaluation and minimization of impacts on Antarctic territories.

\section{Materials and methods}

To quantify the environmental costs associated with the running of the Spanish camp on Byers Peninsula we examined first the green house gas emissions of the transport and camp operation, the use of resources on the camp and the cumulative trampling pressure. Secondly, we estimated the Limnopolar programme's environmental impacts and examined the environmental management practices, based on available data. Finally, the scientific outputs resulting from the group's research at Byers Peninsula were listed.

\section{Quantification of total carbon footprint for the field research camp on Byers Peninsula}

Estimations of greenhouse gas emission per field researcher and per field season (2001/02 to 2009/10) were calculated. Total $\mathrm{CO}_{2}$ equivalent emissions were considered under two headings: 1) direct transportation emissions (including aircraft transport of personnel to gateway ports in South America and transport of personnel by ship from South American ports) plus field camp accommodation and activities, and 2) indirect transport emissions associated with annual cargo transportation by ship from Spain.

Spanish Antarctic land-based research is focused predominantly on the South Shetland Islands. Thus, all researchers reach Antarctica by flying to gateway ports in South America and sailing to the Antarctic Peninsula. Researchers were assumed to have departed from the largest airport of their home country. Emissions derived from air transportation to gateway ports were calculated using the methodology of Amelung \& Lamers (2007) and Farreny et al. (2011), where $\mathrm{CO}_{2}$ equivalent emissions are obtained from fuel conversions. Punta Arenas (Chile) via Santiago was the main gateway port for air transport distance calculations. The alternative route of Ushuaia (Argentina) via Buenos Aires is roughly similar in total distance covered.

Data on oil consumption and total distance covered by the Oceanographic Research Vessel (BIO) Las Palmas were provided by the Spanish Navy. Distance covered was measured from: i) Spain to the South American gateway ports and back once per year (indirect costs), ii) from South American gateway ports to Antarctica, and iii) travel within the Antarctic Peninsula region (direct costs). This distinction was made to enable a comparison with direct emissions of other vessels.

Long distance cargo transportation and travelling costs for researchers from their home country were included in the $\mathrm{CO}_{2}$ equivalent calculations. Emissions due to cargo were calculated based upon the return voyage from Cartagena in Spain to Punta Arenas in Chile, plus each season's return journeys to Antarctica for delivery of investigators, refuelling, resupply and waste disposal. As the ship also supported other scientists and stations in the area, emissions attributed to supporting science on Byers Peninsula were standardized and assigned proportionally.

$\mathrm{CO}_{2}$-equivalent emission resulting from the camp activities was calculated based on fuel consumption according to International Panel on Climate Change conversion factor (Forster et al. 2007).

\section{Quantification of field camp logistics, occupancy and trampling footprint}

The site logistic and research activities were accounted and analysed in detail to establish and, where possible, quantify 
Table I. Carbon emission directly associated with the Spanish field camp on Byers Peninsula.

\begin{tabular}{|c|c|c|c|c|c|c|c|}
\hline \multirow[t]{2}{*}{ Season } & \multirow[t]{2}{*}{$\begin{array}{c}\text { Season } \\
\text { duration }(\mathrm{d})\end{array}$} & \multirow[t]{2}{*}{$\begin{array}{c}\text { Number of } \\
\text { people }\end{array}$} & \multicolumn{2}{|c|}{$\begin{array}{l}\text { Transportation } \\
\text { emissions }\end{array}$} & \multirow{2}{*}{$\begin{array}{l}\text { Field camp } \\
\text { fuel emissions } \\
\mathrm{CO}_{2}-\mathrm{Eq}(\mathrm{t})\end{array}$} & \multirow[t]{2}{*}{$\begin{array}{c}\text { Total } \mathrm{CO}_{2}-\mathrm{Eq} \\
\text { per season }\end{array}$} & \multirow[t]{2}{*}{$\begin{array}{l}\text { Mean } \mathrm{CO}_{2} \text {-Eq } \\
\text { per researcher }\end{array}$} \\
\hline & & & $\mathrm{CO}_{2}$-Eq flights (t) & $\mathrm{CO}_{2}$-Eq vessel (t) & & & \\
\hline $2002 / 03$ & 39 & 9 & 17.71 & 108.14 & 0.42 & 126.27 & 14.03 \\
\hline 2003/04 & 59 & 7 & 13.87 & 84.11 & 0.63 & 98.61 & 14.09 \\
\hline $2005 / 06$ & 8 & 5 & 9.7 & 60.08 & 0.09 & 69.87 & 13.97 \\
\hline $2006 / 07$ & 83 & 14 & 23.48 & 168.21 & 0.89 & 192.58 & 13.76 \\
\hline $2009 / 10$ & 20 & 7 & 13.58 & 84.11 & 0.21 & 97.9 & 13.99 \\
\hline Mean & 48 & 11 & 21.40 & 132.17 & 0.52 & 154.08 & 13.99 \\
\hline Total & 384 & 88 & 171.17 & 1057.32 & 4.11 & 1232.6 & \\
\hline
\end{tabular}

its potential cumulative environmental impact. Information was collected from the camp annual reports (including data on the daily occupation of the camp) while daily consumptions of camp resources, as well as occupation levels and research activities, were recorded systematically by the Principal Investigator (PI) of Limnopolar project who annually co-ordinated the use of the site.

Information on the routes travelled within Byers Peninsula was collected for the period 2001/02 to 2009/10. Data from 2007/08 season were not available, and no fieldwork was undertaken during 2004/05. Locations within the peninsula and distances between them were recorded using GPS (Garmin Model 60CSx). Information on the number of passes per route was first recorded through dairies from Limnopolar group field participants, but other research groups coincident in time with available recording of their walks in the PI diaries are also included in the calculations. We estimate that all tracks from more than $80 \%$ of Spanish camp hosts are incorporated in the analysis. Passes between the camp and the landing beach were estimated indirectly due to the high frequency of use, by multiplying number of occupants $\times$ days $\times$ four times (i.e. an average of four traverses was estimated for each person per day).
Analysis of local environmental impacts and management actions

Environmental pressures on the local ecosystems are next analysed with identification and status of impacts around the camp, trampling disturbances throughout the ASPA and all impact management efforts. Firstly, the provisions to protect the local values of the ecosystems contained in the ASPA No. 126 Management Plan were reviewed. This included legal obligations concerning environmental protection and management actions detailed in the Environmental Protocol, as well as the ASPA No. 126 Management Plan (ATCM 2011) that contains mandatory provisions put in place to safeguard the area's environmental values.

Identification of impact were based primarily upon provisions from the ASPA management plan, initial observations in the field and existing literature, taking into consideration minimization and mitigation of adopted measures, and monitoring programmes currently in place at the site. The status of impacts was obtained from either previous studies with specific monitoring or indirectly from field reports (such as wastes generated or potential introduction of species), and current calculations of

Table II. Carbon emission indirectly associated with the Spanish field camp on Byers Peninsula.

\begin{tabular}{|c|c|c|c|c|c|}
\hline Season & $\begin{array}{l}\text { Total researchers on } \\
\text { SM Las Palmas }\end{array}$ & $\begin{array}{l}\text { Number of people } \\
\text { on Byers Peninsula }\end{array}$ & Percentage of total $(\%)$ & $\begin{array}{l}\text { Cargo emissions } \\
\mathrm{CO}_{2} \text {-Eq (t) }\end{array}$ & $\begin{array}{c}\text { Mean } \mathrm{CO}_{2}-\mathrm{Eq}(\mathrm{t}) \\
\text { per researcher }\end{array}$ \\
\hline $2001 / 02$ & 50 & 11 & 22.00 & 528.26 & 48.02 \\
\hline 2003/04 & 59 & 7 & 8.42 & 327.69 & 46.81 \\
\hline $2005 / 06$ & 42 & 5 & 11.90 & 320.80 & 64.16 \\
\hline 2006/07 & 67 & 14 & 20.89 & 577.13 & 41.22 \\
\hline $2007 / 08$ & 52 & 4 & 7.69 & 212.46 & 53.11 \\
\hline $2009 / 10$ & 109 & 7 & 6.42 & 177.38 & 25.34 \\
\hline Mean & 68 & 11 & 15.19 & 420.78 & 44.25 \\
\hline Total & 546 & 88 & & 3366.28 & \\
\hline
\end{tabular}


pressures (such as $\mathrm{CO}_{2}$ emissions, trampling footprint) combined with indicator studies. Minor impacts in the wider environment were also listed. To our knowledge no other impacts were associated with the camp in the ASPA.

The trampling disturbances in the ASPA were established according to the carrying capacities of representative terrestrial ecosystems. These have been previously determined by indicator studies: in the case of Tejedo et al. (2009) for soil fauna, where significant damages to open soils was observed after 200 passes, and for plant communities see Pertierra et al. (2013), where lower resistances were found on cryptogam communities. Therefore, the assessment of spatial pressures was based on current pressure intensities resulting from operational logistics in the camp and the trampling impacts around Byers Peninsula according to the previous thresholds.

Finally, the management actions to minimize potential environmental impacts on Byers Peninsula were evaluated at three levels: 1) minimization of the level of pressure on the environment, through the adoption of the precautionary principle (Cooney \& Dickson 2005), 2) mitigation of emerging impacts, and 3) monitoring the ecosystems response to the impact effects.

\section{Results}

Total carbon footprint supporting Byers Peninsula camp's field research

Results in Table I and II shows that most carbon emissions are associated with transport of personnel and cargo to the camp from Europe and South America. Personnel transport on ships generated an average of $14 \mathrm{tCO}_{2}$ equivalents per capita, similar to figures calculated for tourist ships. In contrast, indirect emissions calculated for cargo were around $44 \mathrm{tCO}_{2}$ equivalent per capita. To our knowledge there is no data available with which to compare this figure. Field emissions were minimal at less than one ton per year for the whole camp. Overall, the larger the number of researchers per season, the larger the emissions total. In general, $\mathrm{CO}_{2}$ equivalent emission per individual researcher declined as the number of people in the camp increased, probably due to increased sharing of cargo and logistics. As most emissions were due to the transport of personnel and cargo to Antarctica, the duration of the field camp occupancy had little effect upon overall emissions each season, whilst transport had an increased effect.

\section{Field camp logistics, occupancy and trampling footprint}

The field camp opened on 5 December 2001. Since 2001, c. $15000 \mathrm{~kg}$ of cargo have been transported by the BIO Las Palmas and transferred to the shore by inflatable boat and carried inland to the camp without use of land vehicles. The camp facilities comprise two plastic igloos $\left(c .10 \mathrm{~m}^{2}\right.$

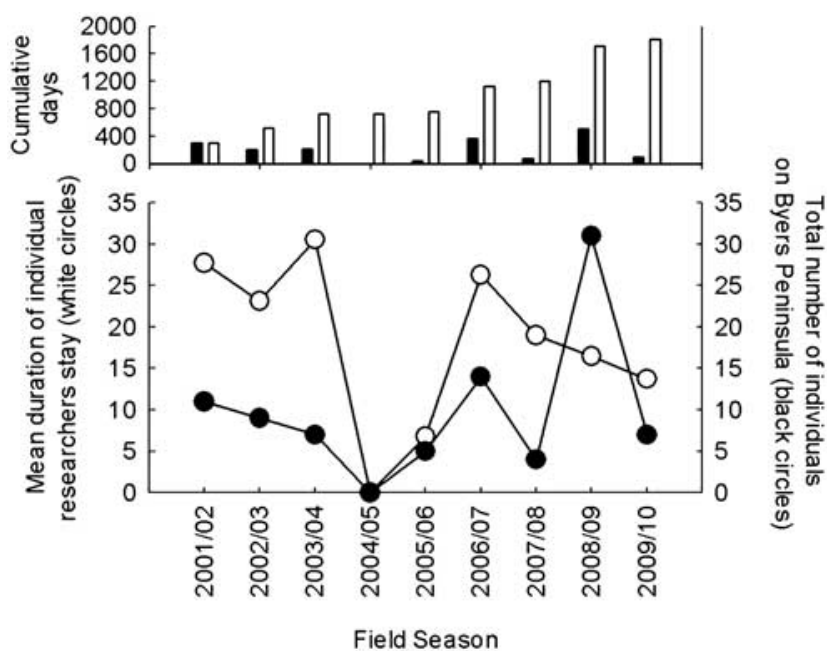

Fig. 2. Occupancy of the Spanish field camp on Byers Peninsula (2001-10). The top graph represents the cumulative number of days spent by researchers at the camp per season (black bars) and in total (white bars). In the bottom graph the white circles represent the mean duration in days of individual researchers at the camp each season. The black circles represent the total number of field researchers staying at the camp each season.

each, one functioning as a laboratory and the other for living), one tent for storage and one tent for each individual person in the camp. The facility was assembled in two phases during November 2001 and November 2002. Once complete, the camp occupied $2592 \mathrm{~m}^{2}$ on a raised beach in sandy ground, c. $110 \mathrm{~m}$ from the coast. Being relatively small the site made little visual impact in the local area (Summerson \& Riddle 2000). Thus, the visual impact of Byers Peninsula camp is considered minimal due to the small-scale of the year-round camp facilities (igloo huts), although paths are also visible after surface snow has melted.

To date, the camp has been used for eight seasons (2001/02 to 2009/10, but excluding 2004/05 when the camp remained closed). The eight seasons allowed a total of 88 individual stays in the camp, with an average stay of 20.58 days per person. The cumulative number of person days spent on Byers Peninsula during the period 2001-10 is 1811 days (equivalent to five individual person years). Up to 31 researchers have stayed at the camp during any one season, with duration of their stay varying between 7 and 31 days. Researchers from 13 different nations have stayed there, particularly during the 2008-09 seasons when the camp was used by an IPY project. Persistent noise levels were limited to the generator. Figure 2 shows the level of occupancy of the camp since first established.

The $3.5 \mathrm{~kW}$ generator used an estimated 3.74 litres of oil per day. The generator was only used for scientific or domestic purposes and fuel consumption was independent of the number of researchers in the camp. To reduce waste and grey water production food was pre-cooked and frozen 

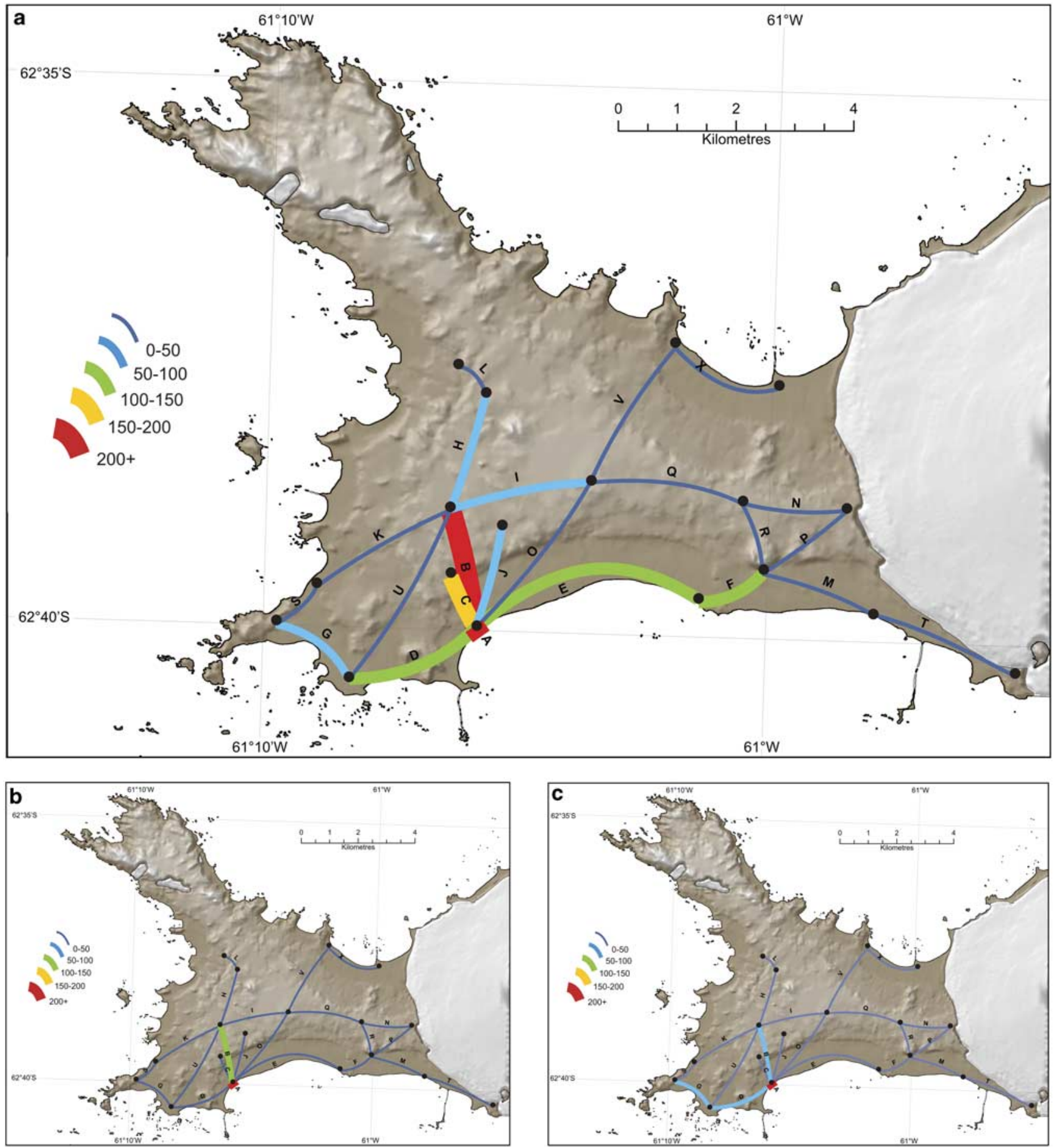

Fig. 3. Trampling footprint on Byers Peninsula of the Spanish Antarctic Programme 2001-10, excluding 2004/05 (no field season) and 2007/08 (no data). a. The distribution and cumulative number of estimated passes during the period of the camp. b. \& c. The distribution and number of estimated passes during the International Polar Year (2008/09) and 2003/04 seasons, respectively.

in Juan Carlos I Spanish Station $(<40 \mathrm{~km}$ away) and sent to the camp with other cargo. Freshwater for cooking and cleaning was obtained from a nearby stream. The drinking water was hand-filtered through a small water purifier. Estimated water consumption was five litres per person per day and c. $5.5 \mathrm{~m}^{3}$ in total for the camp during a typical season. To avoid contamination of the freshwater systems, human liquid waste was collected in plastic bottles and emptied into the sea below the low tide line. Human solid wastes were collected and sent into the waste streams on 
Table III. Impact management for the Limnopolar expedition on Byers Peninsula. Impact management has been divided in three levels of action: i) minimization of the intensity of the pressure, ii) mitigation of the possible adverse impacts, and iii) monitoring of the environmental response.

\begin{tabular}{llll}
\hline Impact & i) Minimization of pressures & ii) Mitigation of impacts & iii) Monitoring of response \\
\hline $\begin{array}{l}\text { Soil and vegetation } \\
\text { trampling }\end{array}$ & $\begin{array}{l}\text { No more than eight people staying at } \\
\text { the same time in the camp. Planned } \\
\text { and co-ordinated field activities. }\end{array}$ & $\begin{array}{l}\text { Concentration in a field camp; } \\
\text { concentration in frequented paths; }\end{array}$ & $\begin{array}{l}\text { Adverse effects in the camp area } \\
\text { on soil physical properties and } \\
\text { Avoiding sensible biotopes. }\end{array}$ \\
& & & edaphic fauna. Recovery \\
estimated inc. 3-5 years.
\end{tabular}

Species introduction Bio-security procedures: dedicated clothing, decontamination of boots, and safety check-list for cargo.

Faunal disturbance

Minimization of light, noise and vibration from camp and expeditions. Avoiding bird and mammal concentrations (resting seals).

Soil pollution

No dumping of any waste, use of sterile materials, avoiding the use of potentially dangerous products.

Stream water contamination
Water supply from stream for drink and personal cleanliness use only. Purification based on tablets. Dry cleaning of materials with no use of washing products.
Equipment cleaning measures implemented. Avoiding lake cross-contamination by use of different mouthpieces.

Precautionary distance procedures followed. Generator shut with no electric demand.

Field camp designed as a contention area with fast dispersion and renewal. Solid waste removed from the area and treated.

Separation of waste: storage of human solid waste. Urine stored and evacuated at sea. Other liquids stored and removed.
Non-native species introductions not detected. Systematic surveys.

Impacts not detected. Not monitored but no unusual record.

Sporadic surveys of soil pollution: organic pollutants and heavy metals.

Water use quantified. Water quality not monitored due to zero residual output. the ship to be managed with other rubbish. Camp rubbish was separated into organic and non-organic material and stored until it was shipped out. Waste consisted mostly of plastic packaging from food and laboratory materials. All bagged waste was shipped to South America for disposal whilst human waste was disposed of through a sewage waste treatment plant. No detailed record of the quantity of solid waste produced is available, but is estimated at around $450 \mathrm{~kg}$ for the period 2001-10. All chemical waste was stored in appropriate containers and disposed of through Universidad Autónoma de Madrid (Spain) facilities.

To estimate the trampling footprint on Byers Peninsula Fig. 3a shows the total number of passes recorded along each route between 2001 and 2010, with most recorded journeys to the landing beach (estimated as 6736 passes) and Limnopolar Lake (636 passes) where defined paths had developed. Limnopolar Lake was the main study site and the site of an automatic meteorological station. Other routes had fewer passes and in most cases, no visible tracks existed, so trampling was more diffuse. Figure $3 \mathrm{~b} \& \mathrm{c}$ shows results for two individual years which represent different patterns of research. Figure $3 b$ shows movements during a period of focused research by limnologists (2003/04), while Fig. 3c shows movements during a year of more diversified research activity (2008/09).

\section{Local environmental impacts and management actions}

Five main categories of environmental values were described for Byers Peninsula: 1) large areas of ice-free soils (López-Martínez et al. 1996, Navas et al. 2008), 2) extensive vegetation moss meadows and microbial mats (Lindsay 1971), 3) terrestrial (Tejedo et al. 2009) and 4) marine biodiversity, and 5) the unique concentration of freshwater bodies (Toro et al. 2007, Quesada et al. 2009).

These values were vulnerable to the following impacts: i) soil and vegetation trampling by researchers, ii) nonnative species introduction to the area, particularly around areas of intense human activity, i.e. the camp and Limnopolar Lake, iii) disturbance of fauna around the camp and the landing beach, iv) pollution of soils around the camp, and v) contamination of freshwater bodies.

Trampling (Tejedo et al. 2009) was considered to be the greatest environmental pressure to the protected values due to the field activities of the researchers throughout the peninsula (see Table III \& Fig. 3), although research has shown the terrestrial environment to be largely resilient to trampling over the past ten years, with recovery occurring within approximately five years if trampling is halted (Tejedo et al. in press). The movement of personnel and cargo into Byers Peninsula presented the opportunity for the introduction of non-native species (Frenot et al. 2005, Convey et al. 2006), but none were observed by biologists at the site, although no systematic survey was undertaken.

Human interaction with wildlife was kept to a minimum. The landing site contained large numbers of elephant seals, which were avoided to the maximum extent possible. Here a low interaction is expected to produce no disturbance according to Burton \& Van den Hoff (2002). A petrel breeding colony located west of the camp was largely 
avoided as suggested by Pfeiffer (2005). Contact with marine mammals at the camp was rare as the camp was far enough inland to discourage animal visits. The penguin colony, located at Devils Point $c .5 \mathrm{~km}$ away, was visited rarely, following recommendations by Cobley \& Shears (1999) and Holmes et al. (2008). Barbosa et al. (2013) documented Devils Point colony health as a reference location to other sites.

In the case of pollutants the release of fuel to the environment was limited to very small quantities discharged by the engines of inflatable boats during landings at the beach. No oil spills were reported in the camp area, and the possibility of minor spills during refuelling of the generator was minimized by using spill trays and oil absorbing mats. Water bodies were considered unaffected with no fuel spills reported in the stream near the camp or in the lakes. Air pollution was restricted to emissions from the generator. Cabrerizo et al. (2012) recorded soil pollution around the camp.

Management actions primarily focused on the impacts in the camp area, and developing trampling strategies around the peninsula. Table III shows the list of management actions and scientific data collected by researchers to reduce impacts by the Limnopolar expedition on Byers Peninsula.

\section{Discussion}

Global costs and logistics operations

In this study we have attempted to estimate the environmental pressures and likely impacts of ten years of research at a remote field camp on Byers Peninsula (Tables I \& II). Greenhouse gas emissions are still a normal component of the environmental cost of research in remote areas, but are insignificant compared to greenhouse gas emissions globally and justified by the benefit Antarctic science has made to our understanding of global and regional climate change (Vaughan et al. 2003, Steig et al. 2009). Total carbon emissions are predominantly from transport showing similar values $\left(c .14 \mathrm{tCO}_{2}\right.$ equivalent emissions) to those obtained for Antarctic tourism cruises (Farreny et al. 2011). Efforts to reduce fuel use and associated emissions have been made by COMNAP, although this may be driven by concerns over increases in the cost of fossil fuels, as well as for environmental reasons (Tin et al. 2009). Since most $\mathrm{CO}_{2}$ is emitted during transport of cargo and personnel and very little with the actual running of the camp, science output might be enhanced with little increase in greenhouse emissions by increasing the duration of time at the field site. Nevertheless, this may have to be balanced against any increase in other, more local, environmental pressures and science requirements.

Given the vulnerability and uniqueness of Byers Peninsula, as recognized by its status as an ASPA, efforts should be focused on minimizing local environmental impacts. With this in mind the Spanish Camp was re-designated as an International Field Camp in 2010, making it available to scientist from other nations, and focusing impacts on this existing impacted site. Inevitably, the camp area has experienced cumulative impacts predominantly through trampling of the camp area. The igloo huts were made available for other scientists to use, following consultation with the Spanish Polar Committee.

\section{Availability of information intended to reduce impacts}

Anyone undertaking Antarctic research in Byers Peninsula ASPA (or any other Antarctic location) should look for guidance to help ensure environmental impacts are kept to a minimum. The Protocol on Environmental Protection to the Antarctic Treaty sets out minimum standards of environmental protection. Annex V of the Protocol provides guidance on Antarctic Protected Areas including ASPAs. Each ASPA has a management plan, which should set out mandatory and site-specific requirement to ensure a level of environmental protection but with no impact studies nor impact monitoring in the majority of ASPAs there is little information on the level of human impacts most ASPAs can withstand/recover from, and decisions on appropriate levels of human activity within ASPAs is generally guesswork, if considered at all. A lack of co-ordination between Parties makes implementation of any limits of human activity difficult if not impossible. During the revision of the Byers Peninsula ASPA Management Plan in 2010, undertaken by the United Kingdom, Spain and Chile, new strategies were developed to further improve environmental standards and minimize human impacts. These included the designation of the field camp as an International Field Camp, marking of visible paths to encourage the concentration of trampling impacts on ground disturbed already and designation of zones where access is restricted. A summary of human impact to that point was also included in the management plan.

\section{Management of field activities and associated impacts}

Earlier studies have shown that research on Byers Peninsula may result in potential impacts on the environment (Tejedo et al. 2009) but this should not compromise the qualities and characteristics of the site that make it of value (including scientific value) in the first instance. However, monitoring is required to ensure that the ecosystems are resilient, are not being damaged permanently, that human presence is below the carrying capacity for the location (Table III) and to identify any new activities that produce threats to the Antarctic environment. In the case of trampling management the SCAR Code of Conduct (2009) indicates one basic strategy: follow existing paths when necessary in order to avoid disturbing large areas. For this reasons two frequently 
used paths (to landing beach and to Limnopolar Lake) were defined. For Byers Peninsula, soil recovery rates from trampling impacts were considered acceptable ( $3-5$ years; Tejedo et al. in press), although it is clear from Fig. 3 that the distribution and intensity of trampling impacts will vary depending upon the type and requirements of the science performed in any given year (see Fig. $3 b \&$ c). Biosecurity measures were used to reduce the risk of non-native introductions, but given the rate of climate warming in the region and the level of visitation, Byers Peninsula may be particularly vulnerable to non-native species introductions (Hughes \& Convey 2010, CEP 2011). Looking forward, a similar strategic use of the Byers Peninsula ASPA, including periods when some sites are not visited to allow recovery, may be appropriate. To date, a strategic management approach has been difficult to achieve as each nation operating in the area is acting independently and multi-party coordination of activities, in practice, has not occurred, despite this recommendation within the ASPA management plan. Given that human presence at the site is unlikely to cease, restrictions with higher standards could be applied in order to minimize environmental impacts and protect some zones for specific scientific purposes. To some extent, this has been done recently within the Byers Peninsula ASPA with the creation of two zones where access is restricted to those undertaking molecular and microbiological research with appropriately high quarantine standards (see http:// www.ats.aq/documents/recatt/att474_e.pdf).

\section{Optimization of science and outreach}

Application of basic environmental standards, adequate management and appropriate knowledge of the resilience of the area to impacts can minimize the likelihood of irreversible impacts. Nonetheless impacts on the area are only permitted by research safeguarding the natural and scientific values in this protected area according to the management plan. Here, the isolation and pristine nature of the water bodies in Byers Peninsula make it an exceptional site for limnological research (Quesada et al. 2009). Scientists undertaking research in remote areas that could be considered pristine face the paradox that the research itself may cause environmental degradation at some level. It could be argued that only research attempting to answer the most critical science questions should be undertaken in such locations as their value for future science might be diminished (see Hughes et al. 2011). Although potentially controversial, the benefit of undertaking each science project in Antarctica may need to be balanced against the environmental impact and, in some cases, the irreversible change it may cause. For precautionary reasons all research activities in Antarctica should at least maximize the scientific benefits. In the case of the Limnopolar group every effort was made to publish data in peer-reviewed journals and to use this science to inform the revision of the
ASPA management plan. Scientific outputs were also optimized by involving experts from a range of disciplines from other nations, particularly as part of the IPY. Finally, efforts were made to engage the general public in the work undertaken at the site and its key role for understanding the global change.

An important number of scientific publications including the work undertaken on Byers Peninsula through the Spanish camp (see Benayas et al. 2013) has been achieved between 2001 and 2010, including several high profile publications (López-Bueno et al. 2009, Kleinteich et al. 2012). In the case of the Limnopolar group there have also been six peer-reviewed chapters in scientific books, three non-peer review publications and several articles in popular science magazines. Scientific activity has also resulted in collection of long-term datasets characterizing lakewater and meteorological parameters as well as viral biodiversity surveys, data on human impacts, microbial mat biodiversity surveys, and botanical, permafrost and climate studies. Research also contributed to the major revision of the ASPA management plan completed in 2011. Education has also been an important output of the Limnopolar expeditions to Byers Peninsula, including teaching of science associated with the area in several postgraduate courses and conferences and the training of several Masters and $\mathrm{PhD}$ students. Further publications using or building upon data already collected are expected in the coming years.

\section{Conclusions}

Experience at Byers Peninsula has highlighted the need for continuous environmental management of local impacts during field activities. Management should consider: i) preidentifying possible impacts, ii) adapting logistical practices on a case by case basis, iii) monitoring activities and potential impacts, and iv) initiating specific environmental studies if considered necessary. Spanish scientists have undertaken precautionary monitoring and developed impact minimization strategies. For example, the route to Limnopolar Lake and to the field camp from the beach landing site were designated sacrificial paths to reduce wider impact. To avoid damage to vegetation, scientists were directed to walk on open soil areas instead of mosses, which however, produced disturbance to soil fauna which was consequently the subject of a further monitoring project.

Scientific results from the Spanish camp were exploited through international co-operation with initiatives such as the IPY and a diverse outreach. Operational activities focused on the allocation of other groups interested on Byers Peninsula to avoid as much as possible the duplication of logistics, also the camp facility was re-used as the international field camp. However, much more could be achieved in international coordination of 
activities. Scientific benefits in these sensitive areas need to be balanced against environmental impacts to safeguard their future scientific value.

\section{Acknowledgements}

This paper was contributed to by two projects: LIMNOPOLAR and EBA-ANTARCTICA. It was supported by the Spanish Government (CGL2005-0654, POL2006-06533, CGL2007-28761-E/ANT, CTM200906604-E and CTM2010-11613-E). Permission to inspect the ASPA was granted on 2009/10 season by the Spanish Polar Committee. The publication of this paper has been funded by the grant CTM2011-12973-E by the Ministerio de Ciencia e Innovación (Spain). We would like to thank the Spanish Polar Committee, the SM BIO Las Palmas of the Spanish Navy, the Unit of Marine Technology (UMT) from CSIC, the Spanish Station Juan Carlos I and the UTM members that provided support to Byers Peninsula camp. We thank Peter Fretwell (BAS) for cartographic support and all those on Byers Peninsula who contributed to this research project. This paper also contributes to the British Antarctic Survey Polar Science for Planet Earth (PSPE) Environment Office Long-term Monitoring and Survey project. Finally, we thank the anonymous reviewers for their useful comments.

\section{References}

Amelung, B. \& Lamers, M. 2007. Estimating the greenhouse gas emissions from Antarctic tourism. Tourism in Marine Environments, 4, 121-133.

ATCM (Antarctic Treaty Consultative Meeting). 2011. Management Plan for Antarctic Specially Protected Area No. 126 Byers Peninsula, Livingston Island, South Shetland Islands. Measure 4, Report of the Thirty-fourth Antarctic Treaty Consultative Meeting. Buenos Aires, Argentina. http://www.nsf.gov/od/opp/antarct/aca/nsf01151/ aca2_spa126.pdf.

Ayres, E., Nkem, J.N., Wall, D.H., Adams, B.J., Barrett, J.E., Broos, E.J., Parsons, A.N., Powers, L.E., Simmons, B.L. \& Virginia, R.A. 2008. Effects of human trampling on populations of soil fauna in the McMurdo Dry Valleys, Antarctica. Conservation Biology, 22, 1544-1551.

Barbosa, A., Demas, E., Benzal, J., Diaz, J., Motas, M., Jerez, S., Pertierra, L.R., Benayas, J., Justel, A., Lauzurica, P., Garcia-Peña, F.J. \& Serrano, T. 2013. Pollution and physiological variability in gentoo penguins at two rookeries with different levels of human visitation. Antarctic Science, 25, 10.1017/S0954102012000739.

BAstMeiJer, C.J. \& Roura, R. 2007. Environmental impact assessment in Antarctica. In BastmeiJer, C.J. \& Koivurova, T., eds. Theory and practice of transboundary environmental impact assessment. Leiden: Martinus Nijhoff, 175-219.

Benayas, J., Pertierra, L.R., Tejedo, P., Lara, F., Bermudez, O., Hughes, K.A. \& QuesadA, A. 2013. Review: scientific research trends within ASPA No. 126 Byers Peninsula. Antarctic Science, 25, 10.1017/ S0954102012001058.

Burton, H. \& van Den Hoff, J. 2002. Humans and the southern elephant seal. Mirounga leonine. Australian Mammalogy, 24, 127-139.

Cabrerizo, A., Dachs, J., Barceló, D. \& Jones, K.C. 2012. Influence of organic matter content and human activities on the occurrence of organic pollutants in Antarctic soils, lichens, grass, and mosses. Environmental Science \& Technology, 46, 1396-1405.
Campbell, I.B., Claridge, G.G.C. \& Balks, M.R. 1998. Short and longterm impacts of human disturbance on snow-free surfaces in Antarctica. Polar Record, 34, 15-24.

Clarke, A., Barnes, D.K.A. \& Hodgson, D.A. 2005. How isolated is Antarctica? Trends in Ecology and Evolution, 20, 1-3.

CEP (Committee For Environmental Protection). 2011. Non-native species manual. Secretariat of the Antarctic Treaty, 28 pp. http://ats.aq/ documents/atcm34/ww/atcm34_ww004_e.pdf.

COMnap (Council Of Managers of Antarctic National Programs). 2012. List of Antarctic facilities. https://www.comnap.aq/Members/ Shared\%20Documents/Antarctic_Facilities_List_1April2012.xls.

Connor, M.A. 2008. Wastewater treatment in Antarctica. Polar Record, 44, 165-171.

Convey, P. 2008. Non-native species in Antarctic terrestrial and freshwater environments: presence, sources, impacts and predictions. In RogaNFinNemore, M., ed. Non-native species in the Antarctic Proceedings. Christchurch: University of Canterbury, 97-130.

Convey, P., Frenot, F., Gremmen, N. \& Bergstrom, D. 2006. Biological invasions. In Bergstrom, D.B., Convey, P. \& Huiskes, A.H.L., eds. Trends in Antarctic terrestrial and limnetic ecosystems. Antarctica as a global indicator. Dordrecht: Springer, 193-220.

Cooney, R. \& Dickson, B. 2005. Biodiversity and the precautionary principle: risk and uncertainty in conservation and sustainable use. London: Earthscan, 314 pp.

DE VilLiers, M. 2008. Review of recent research into the effects of human disturbance on wildlife in the Antarctic and sub-Antarctic region. In Human disturbance to wildlife in the broader Antarctic region: a review of findings. Appendix 1, Working Paper 12 for XXXI Antarctic Treaty Consultative Meeting, Kiev, Ukraine, 2-13 June 2008.

De Villiers, M., Bause, M., Giese, M. \& Fourie, A. 2006. Hardly hardhearted: heart rate responses of incubating northern giant petrels (Macronectes halli) to human disturbance on sub-Antarctic Marion Island. Polar Biology, 29, 717-720.

Farreny, R., Oliver-Solà, J., Lamers, M., Amelung, B., Gabarrell, X., Rieradevall, J., Boada, M. \& Benayas, J. 2011. Carbon dioxide emissions of Antarctic tourism. Antarctic Science, 23, 556-566.

Forster, P., Ramaswamy, V., Artaxo, P., Berntsen, T., Betts, R., Fahey, D.W., Haywood, J., Lean, J., Lowe, D.C., Myhre, G., NGanga, J., Prinn, R., Raga, G., Schulz, M. \& Van Dorland, R. 2007. Changes in atmospheric constituents and in radiative forcing. In Solomon, S., Qin, D., Manning, M., Chen, Z., Marquis, M., Averyt, K.B., Tignor, M. \& Miller, H.L., eds. Climate change 2007: the physical science basis. Contribution of Working Group I to the Fourth Assessment Report of the Intergovernmental Panel on Climate Change. Cambridge: Cambridge University Press, 129-234.

Frenot, Y., Chown, S.L., Whinam, J., Selkirk, P., Convey, P., Kotnicki, M. \& Bergstrom, D. 2005. Biological invasions in the Antarctic: extent, impacts and implications. Biological Reviews, 80, 45-72.

Gremmen, N.J.M., Smith, V.R. \& van ToRengen, O.F.R. 2003. Impact of trampling on the vegetation of sub-Antarctic Marion Island. Arctic, Antarctic, and Alpine Research, 35, 442-446.

Holmes, N.D., Giese, M. \& KriwoKen, L.K. 2008. Linking variation in penguin responses to pedestrian activity for best practise management on subantarctic Macquarie Island. Polarforschung, 77, 7-15.

Hughes, K.A. \& Convey, P. 2010. The protection of Antarctic terrestrial ecosystems from inter- and intra-continental transfer of non-indigenous species by human activities: a review of current systems and practices. Global Environmental Change, 20, 96-112.

Hughes, K.A., Fretwell, P., Rae, J., Holmes, K. \& Fleming, A. 2011. Untouched Antarctica: mapping a finite and diminishing environmental resource. Antarctic Science, 23, 537-548.

Kleinteich, J., Wood, S.A., Küpper, F.C., Camacho, A., Quesada, A., Frickley, T. \& Dietrich, D.R. 2012. Temperature-related changes in polar cyanobacterial mat diversity and toxin production. Nature Climate Change, 2, 356-360. 
Lindsay, D.C. 1971. Vegetation of the South Shetland Islands. British Antarctic Survey Bulletin, No. 25, 59-83.

López-Bueno, A., Tamames, J., Velázquez, D., Moya, A., Quesada, A. \& Alcami, A. 2009. High diversity of the viral community from an Antarctic lake. Science, 326, 858-861.

López-Martínez, J., Martínez de Pisón, E., Serrano, E. \& Arche, A. 1996. Geomorphological map of Byers Peninsula, Livingston Island. In López-Martínez, J., Thomson, M.R.A. \& Thomson, J.W., eds. Geomorphological map of Byers Peninsula, Livingston Island. BAS GEOMAP series, sheet 5A, 1:25000, with supplementary text. Cambridge: British Antarctic Survey, 65 pp.

Navas, A., López-Martínez, J., Casas, J., Machín, J., Durán, J.J., Serrano, E., Cuchi, F. \& Mink, S. 2008. Soil characteristics on varying lithological substrates in the South Shetland Islands, Maritime Antarctica. Geoderma, 144, 123-139.

OLECH, M. 1996. Human impact on terrestrial ecosystems in West Antarctica. NIPR Symposium on Polar Biology, Proceedings, 9, 299-306.

Pertierra, L., Lara, F., Tejedo, P., Benayas, J. \& Quesada, A. 2013. Rapid denudation processes in cryptogamic communities from Maritime Antarctica subjected to human trampling. Antarctic Science, 25, 10.1017/S095410201200082X.

PFeIFFer, S. 2005. Effects of human activities on southern giant petrels and skuas in the Antarctic. PhD thesis, Ecology Institute, University of Jena. Available at: www.db-thueringen.de/servlets/derivateservlet/derivate6345/Pfeiffer.pdf.

Quesada, A., Camacho, A., Rochera, C. \& Velázquez, D. 2009. Byers Peninsula: a reference site for coastal, terrestrial and limnetic ecosystem studies in Maritime Antarctica. Polar Science, 3, 181-187.

SCAR (Scientific Committee On Antarctic Research). 2009. Environmental code of conduct for terrestrial scientific field research in Antarctica. http://www.scar.org/researchgroups/lifescience/Code_of_ Conduct_Jan09.pdf.
Smith, R.I.L. \& Simpson, H.W. 1987. Early nineteenth century sealer refuges on Livingston Island, South Shetland Islands. British Antarctic Bulletin, No. 74, 49-72.

Snape, I., Gore, D.B., Cole, C.M. \& Riddle, M.J. 2002. Contaminant dispersal and mitigation at Casey Station: an example of how applied geoscience research can reduce environmental risks in Antarctica. Royal Society of New Zealand Bulletin, No. 35, 641-648.

Steig, E.J., Schneider, D.P., Rutherford, S.D., Mann, M.E., Comiso, J.C. $\&$ Shindell, D.T. 2009. Warming of the Antarctic ice sheet surface since the 1957 International Geophysical Year. Nature, 457, 459-462.

Summerson, R. \& Riddle, M.J. 2000. Assessing wilderness and aesthetic values in Antarctica. In Davison, W., Howard-Williams, C. \& BROADY, P., eds. Antarctic ecosystems: models for wider ecological understanding. Christchurch: Caxton Press, 303-307.

Tejedo, P., Justel, A., Benayas, J., Rico, E., Convey, P. \& Quesada, A. 2009. Soil trampling in an Antarctic Specially Protected Area: tools to assess levels of human impact. Antarctic Science, 21, 229-236.

Tejedo, P., Pertierra, L., Justel, A., Benayas, J., Convey, P. \& Quesada, A. In press. Trampling on Maritime Antarctica: can soil ecosystems be effectively protected through existing codes of conduct? Polar Research.

Tin, T., Fleming, Z.L., Hughes, K.A., Ainley, D.G., Convey, P., Moreno, C.A., Pfeiffer, S., Scott, J. \& Snape, I. 2009. Impacts of local human activities on the Antarctic environment. Antarctic Science, 21, 3-33.

Toro, M., Camacho, A., Rochera, C., Rico, E., Bañón, M., FernándezValiente, E., Marco, E., Justel, A., Vincent, W.F., Avendaño, M.C., Ariosa, Y. \& Quesada, A. 2007. Limnological characteristics of the freshwater ecosystems of Byers Peninsula, Livingston Island, in Maritime Antarctica. Polar Biology, 30, 635-649.

Vaughan, D.G., Marshall, G.L., Connolley, W.L., Parkinson, C., Mulvaney, R., Hodgson, D.A., King, J.C., Pudsey, C.J. \& Turner, J. 2003. Recent rapid regional climate warming on the Antarctic Peninsula. Climatic Change, 60, 243-274. 